\title{
Pengembangan Aplikasi E-Modul Interaktif Berbasis Android Materi Sistem Peredaran Darah Manusia Kelas V Sekolah Dasar
}

\author{
Yusuf Abyan Rofiyadi ${ }^{1)}$, Sri Lestari Handayani ${ }^{2)}$ \\ 1) Universitas Muhammadiyah Prof. Dr. Hamka, Jakarta, Indonesia \\ E-mail: yusufabyan0@gmail.com \\ ${ }^{2)}$ Universitas Muhammadiyah Prof. Dr. Hamka, Jakarta, Indonesia \\ E-mail: srilestarih@uhamka.ac.id
}

\begin{abstract}
Abstrak. Dunia yang sudah memasuki era revolusi industri 4.0 serta adanya aturan penerapan pembelajaran daring di Indonesia menjadi sebuah peluang untuk dapat memberikan inovasi pembelajaran yang efektif dan efisien serta mengikuti perkembangan zaman. Penelitian ini bertujuan untuk mengembangkan e-modul interaktif berbasis android pada pokok materi sistem peredaran darah manusia untuk siswa kelas 5 sekolah dasar dan menguji kelayakan e-modul yang dihasilkan supaya bisa dimanfaatkan dalam pembelajaran. Metode penelitian yang digunakan adalah Research and Development $(R \& D)$ dengan menerapkan model pengembangan $4 \mathrm{D}$. Instrumen yang digunakan angket validasi untuk beberapa ahli materi, ahli media, dan ahli modul, serta angket respons. Hasil penelitian dari produk yang dikembangkan berdasarkan penilaian dari ahli materi mendapat kriteria baik dengan rerata skor persentase 79,6\%, penilaian dari ahli media mendapat kriteria baik dengan rerata skor persentase $83,8 \%$, dan hasil penilaian dari ahli modul mendapatkan kriteria baik juga dengan rerata skor persentase sebesar 83,3\%. Untuk hasil dari respons siswa mendapat skor persentase sebesar 86,6\% dengan kriteria sangat baik. Berdasarkan hasil perolehan data dapat disimpulkan bahwa e-modul interaktif berbasis android ini layak digunakan sebagai sumber belajar bagi siswa kelas 5 sekolah dasar. Implikasi emodul interaktif ini dapat meningkatkan produktivitas kegiatan belajar mengajar dengan minimnya tenaga.
\end{abstract}

Keywords: Pengembangan E-Modul, E-Modul Interaktif, Berbasis Android, Siswa Sekolah Dasar

\begin{abstract}
The world which has entered the era of industrial revolution 4.0 and the rules for implementing online learning in Indonesia is an opportunity to be able to provide effective and efficient learning innovations and keep up with the times. This study attempts to develop an android based of interactive e-module in the subject of human circulatory system for $5^{\text {th }}$ grade primary school students and test the appropriateness of this product. The research methodology used is research and development (R\&D) by applying development model of 4D. The instruments used to collect data were questionnaire validation for several material experts, media experts, and module experts, as well as student responses questionnaire. The result of this product based on the assessment of material experts got good criteria with an average percentage score of $79,6 \%$, then the assessment from media experts got good criteria with an average percentage score of $83,8 \%$, and the result of assessment from the module experts got good criteria with an average percentage score of $83,3 \%$. For the result of the student responses got a percentage score of $86,6 \%$ with very good criteria. Based the result of the data can be concluded that this android based of interactive e-modul suitable for use as a learning source for $5^{\text {th }}$ grade primary school students. The implication of this interactive e-modul is that it can increase the productivity of teaching and learning activities with a minimum of manpower.
\end{abstract}

Keywords: Development of E-Module, Interactive E-Modul, Android Based, Primary School Students

\section{PENDAHULUAN}

Perubahan zaman selalu diiringi dengan berkembangnya teknologi yang semakin maju, hal ini tidak dapat dihindari melainkan harus dapat beradaptasi dan mengikutinya. Saat ini dunia pun sudah mulai memasuki era revolusi industri 4.0, yang mana hal tersebut ditandai dengan besarnya kemajuan teknologi disertai perubahan sosial ekonomi dan budaya yang juga signifikan. Perkembangan teknologi ini berpengaruh pada berbagai sektor kehidupan, tidak terkecuali pendidikan. Fenomena tersebut menuntut pendidik maupun calon pendidik 
untuk dapat menguasai serta beradaptasi dengan teknologi baru dan tantangan global, karena untuk menghadapi era ini perlu adanya pendidikan yang kreatif, inovatif, dan juga kompetitif (Lase, 2019). Terlebih pendidikan juga menjadi salah satu faktor penting yang dapat mengantarkan keberhasilan dan kesuksesan manusia dalam kehidupannya (Khairunnisa, 2019). Hal tersebut dapat dicapai dengan mengoptimalkan pemanfaatan teknologi sebagai sarana pendidikan, dengan harapan dapat menghasilkan lulusan yang mampu menjawab tantangan zaman.

Berbagai strategi untuk menghasilkan lulusan tersebut salah satunya dengan mengembangkan bahan ajar. Bahan ajar yang dapat dikembangkan salah satunya adalah modul (Sidiq dan Najuah, 2020). Modul adalah bahan ajar yang dirancang secara sistematis dari satu program atau materi tertentu dalam bentuk unit pembelajaran terkecil dan dapat dipelajari secara mandiri oleh peserta didik dapat supaya belajar dapat lebih terarah (Purwanto dkk, 2007). Namun pada saat ini sebagian besar modul masih dibuat dalam bentuk cetak, sebenarnya modul-modul tersebut dapat dikembangkan dalam bentuk elektronik yang dapat digunakan pada perangkat elektronik sehari-hari seperti laptop atau smartphone. Modul elektronik (e-modul) juga dapat dijadikan produk interaktif karena dapat disisipi gambar, video, audio, dan juga animasi. Sehingga dapat lebih menarik peserta didik untuk menggunakannya dan termotivasi untuk lebih aktif dalam belajar seperti mengamati gambar, video, dan mengisi latihan serta kuis yang dapat memberikan umpan balik secara otomatis dan langsung (Herawati dan A. Muhtadi, (2018). Terlebih e-modul interaktif dapat diakses dengan mudah melalui perangkat elektronik sehari-hari yang mana pada zaman ini penggunaan perangkat seperti smartphone banyak diminati berbagai kalangan masyarakat termasuk peserta didik, bahkan proses belajar mengajar pun saat ini sudah banyak dilakukan dengan menggunakan smartphone.

Pada kenyataannya, penggunaan smartphone untuk pendidikan, khususnya di kalangan peserta didik masih kurang dimanfaatkan dengan baik, mereka hanya menggunakannya sebagai media hiburan semata. Terlebih pada saat ini pembelajaran jarak jauh diberlakukan akibat masih maraknya penyebaran Covid-19, sehingga proses PJJ perlu menggunakan perangkat elektronik salah satunya smartphone. Penggunaan berbagai media dalam pelaksanaan PJJ sudah digunakan, seperti Zoom, Grup WhatsApp, Google Meet, Quipper, dan lainnya (Kusuma dan Hamidah, 2020). Namun berdasarkan hasil observasi yang telah dilakukan sebelumnya masih banyak guru kurang memanfaatkan berbagai media dan hanya menggunakan media umum yang sudah ada seperti Grup WhatsApp dan juga YouTube pada proses PJJ, fitur pada media tersebut kurang mendukung terlebih pada pembelajaran IPA. Hal ini disebabkan belum ditentukannya aplikasi yang digunakan untuk pembelajaran daring oleh pihak sekolah sehingga membuat guru kebingungan dan kurang menguasai aplikasi yang akan digunakan, karenanya mereka hanya menggunakan yang sudah ada dan dikuasai (Rasyidiana, 2021). Untuk itu perlu adanya inovasi pada proses pembelajaran dengan mengembangkan e-modul interaktif berbasis android ini.
E-modul interaktif dapat diwujudkan dengan memanfaatkan smartphone yang menggunakan sistem operasi android, mengingat pada saat ini smartphone yang paling banyak digunakan adalah android. Istiyanto, (2013). Android adalah sistem perangkat lunak berbasis linux yang diperuntukan secara open source (terbuka) yang mencakup sistem operasi, middleware, dan aplikasi dasar. Karena sifatnya yang terbuka memungkinkan kita untuk dapat membuat dan mengembangkan suatu aplikasi. Dengan adanya pengembangan aplikasi e-modul interaktif berbasis android ini memungkinkan siswa untuk mengoptimalkan smartphone mereka secara tepat dan menjadi alat belajar yang menyenangkan.

Hasil penelitian Herawati dan A. Muhtadi, (2018) menyatakan e-modul interaktif dalam kepingan Compact Disc (CD) yang dilengkapi berbagai komponen media efektif sebagai sumber belajar mandiri dan mempengaruhi hasil belajar siswa SMA. Penelitian Sidiq dan Najuah, 2020). menyatakan e-modul interaktif berbasis android lebih efisien dalam pembelajaran dan efektif untuk meningkatkan hasil belajar mahasiswa dalam proses pembelajaran. Liana, Y. R. \& Ellianawati, W. Hardyanto, (2019) menyatakan e-modul interaktif berbasis android dengan Sigil Software materi listrik dinamis mampu meningkatkan pemahaman konsep listrik dinamis. Penelitian Setiyani, Dkk (2020) menjelaskan modul digital berbasis keterampilan komunikasi matematika menjadi alternatif sumber belajar yang tidak monoton dan valid, namun perlu dibuat yang mendukung telepon seluler agar penggunaannya tidak terbatas di kelas saja. Accraf, Suryati \& Khery, (2018) menyatakan e-modul interaktif berbasis android materi ikatan kimia dan gaya antar molekul valid dan layak untuk digunakan pada skala luas. Accraf, Suryati \& Khery, (2017) menyatakan e-modul interaktif menggunakan adobe flash pada materi ikatan kimia layak digunakan dan cukup efektif untuk mendorong kemampuan literasi sains siswa. Dari penelitan-penelitian tersebut mendorong peneliti untuk mengembangkan e-modul interaktif ini sebagai salah satu bahan ajar yang dapat digunakan untuk pelaksanaan pembelajaran jarak jauh (PJJ).

Beberapa software dapat digunakan untuk membuat suatu aplikasi, salah satunya dengan bantuan software iSpring Suite dan Website 2 APK Builder. ISpring Suite merupakan software tambahan untuk Microsoft PowerPoint yang memiliki fungsi untuk mengubah file dengan format presentasi (.ppt) ke dalam bentuk HTML5 (flash). Menurut Wulandari, (2020) iSpring Suite adalah salah satu tool yang kompatibel dan dapat diintegrasikan dengan Microsoft PowerPoint dan memiliki berbagai fitur untuk dapat menyisipkan berbagai bentuk media. Format file yang telah diubah ke dalam bentuk HTML5 dapat dikonversi menjadi format .apk atau aplikasi android dengan software Website 2 APK Builder. Biasanya dalam membuat aplikasi android dibutuhkan kemampuan dalam bahasa pemrograman, namun dengan software Website 2 APK Builder ini dapat dimanfaatkan dengan mudah bagi yang kurang memiliki keahlian dalam bahasa pemrograman. 
Kemudahan dalam membuat dan mengembangkan aplikasi melalui software-software tersebut dapat dimanfaatkan untuk membuat pembelajaran menjadi lebih menarik, karena bahan ajar yang memanfaatkan smartphone masih belum banyak ditemukan khususnya pada pembelajaran muatan IPA sekolah dasar. Solusi untuk masalah tersebut adalah perlunya pengembangan aplikasi e-modul interaktif yang mudah digunakan baik secara mandiri maupun dengan arahan guru. Aplikasi ini dapat dikatakan sebagai bahan ajar yang menarik, fleksibel, dan sesuai dengan tuntutan perkembangan zaman saat ini.

Penelitian ini memiliki tujuan untuk mengembangkan emodul interaktif berbasis android dan menguji validitasnya. Perbedaan dari penelitian yang dikembangkan sebelumnya adalah terletak pada bentuk dan juga materi. Bentuk akhir pada pengembangan e-modul interaktif ini berupa aplikasi android (.apk) dan isi materi yang diambil adalah pokok materi IPA Sistem Peredaran Darah Manusia pada tema 4 kelas V sekolah dasar..

\section{METODE}

Metode penelitian yang digunakan dalam penelitian ini menggunakan metode penelitian pengembangan. Metode penelitian ini digunakan untuk menghasilkan produk tertentu serta menguji keefektifan produk tersebut Sugiyono (2016). Pada penelitian pengembangan produk yang dihasilkan dapat diuji untuk dapat dimanfaatkan oleh masyarakat (Wulandari, 2020). Secara umum, penelitian pengembangan bertujuan untuk membuat produk, menguji keefektifan nya, dan memungkinkan untuk digunakan oleh masyarakat luas.

Penelitian ini menerapkan model pengembangan 4D (Define, Design, Development, Disseminate) yang mana bisa diadaptasikan menjadi 4P (Pendefinisian, Perancangan, Pengembanganm dan Penyebaran) Wahyudi, (2019). Melalui tahapan-tahapan model yang digunakan, pengembangan akan dimulai dengan tahap pendefinisian sampai ke tahap penyebaran. Pada tahap pendefinisian, dilakukan analisis masalah dan kebutuhan peserta didik, analisis materi, penentuan kompetensi dan tujuan. Pengumpulan data dilakukan dengan observasi, melalui tahap tersebut peneliti mengetahui isi dari produk yang akan dikembangkan. Pada tahap perancangan akan membuat rancangan produk, kegiatan yang dilakukan adalah penyusunan materi, penyusunan tes acuan, pemilihan media, pemilihan format, dan rancangan awal. Tahap pengembangan dilakukan pengujian produk oleh tim validasi ahli media, ahli materi, dan ahli modul. Hasil pengujian tersebut akan digunakan sebagai sumber revisi yang akan menghasilkan produk tahap 2 untuk nantinya siap digunakan pada uji coba terbatas. Dan tahap penyebaran, produk yang sudah dikembangkan akan coba digunakan melalui pendistribusian dalam jumlah terbatas. Penyebaran dalam penelitian ini masih dibatasi pada SDN Kalisari 02 Pagi saja sebagai tempat penelitian dilakukan.

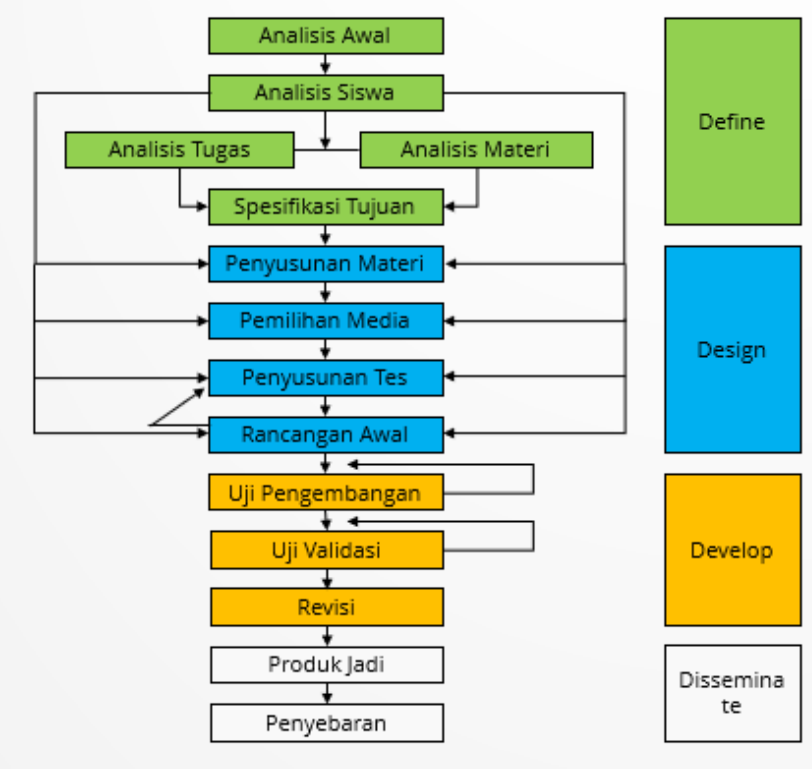

Gambar 1. Alur Pengembangan 4D

Prosedur pengumpulan data pada penelitian pengembangan ini menggunakan teknik observasi dan angket untuk memperoleh data. Menurut Hasanah (2016), observasi tidak hanya proses mengamati dan mencatat, tetapi juga memudahkan untuk mendapat informasi tentang dunia sekitar kita.Untuk itu observasi perlu dilakukan guna mengetahui informasi-informasi di sekitar kita yang dibutuhkan. Observasi ini dilakukan untuk mengetahui masalah dam kebutuhan dari siswa sementara angket digunakan sebagai sumber evaluasi produk yang dikembangkan dari hasil data penilaian dan masukan para ahli materi, ahli media, dan ahli modul. Skala Likert digunakan dalam penyusunan angket penelitian untuk mengetahui kelayakan dari produk yang dikembangkan. Pengumpulan data pada pengembangan modul ini menggunakan data kualitatif berupa masukan dari para ahli dan juga data kuantitatif berupa data skor penilaian dari para ahli yang menjadi validator. Sumber data dalam penelitian ini adalah 6 orang ahli yang terdiri dari 2 orang ahli materi, 2 orang ahli media, dan 2 orang ahli modul. Data yang diperoleh dari hasil uji validasi oleh para ahli akan dihitung menggunakan skala Likert poin 1 sampai 4 dengan pemberian skor yang digunakan (Sugiyono, 2016)

Tabel I

Skala Likert untuk penilaian

\begin{tabular}{cc}
\hline Alternatif Jawaban & Bobot Skor \\
\hline Sangat Baik & 4 \\
Baik & 3 \\
Tidak Baik & 2 \\
Sangat Tidak Baik & 1
\end{tabular}

Selanjutnya untuk mengukur tingkat validitas dari hasil penilaian oleh para ahli, dilakukan analisis dengan teknik deskriptif yang dihitung dengan rumus berikut (Liana, 2019).

$$
\text { Persentase Skor }=\frac{\sum \text { skor perolehan }}{\sum \text { skor maksimum }} \times 100 \%
$$




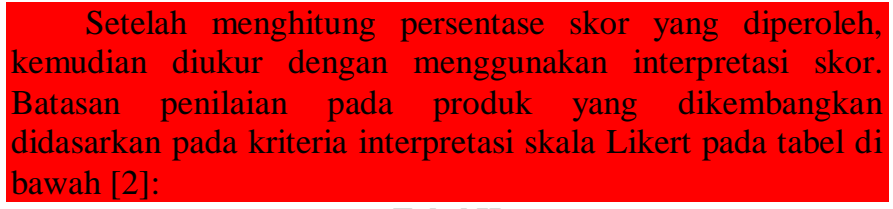

Tabel II

Rentang Persentase dan Kriteria Kelayakan Modul

\begin{tabular}{cc}
\hline Rentang Persentase & Kriteria \\
\hline $86 \%-100 \%$ & Sangat Baik \\
$76 \%-85 \%$ & Baik \\
$60 \%-75 \%$ & Cukup \\
$<55 \%-59 \%$ & Tidak Baik \\
\hline
\end{tabular}

\section{HASIL DAN PEMBAHASAN}

Produk hasil dari penelitian dan pengembangan ini adalah e-modul interaktif pada materi sistem peredaran darah manusia dalam bentuk aplikasi android untuk siswa kelas V Sekolah Dasar yang lebih fleksibel penggunaannya. Produk emodul interaktif ini diberi nama "Modul SiPeDaM" sebagai bahan ajar yang digunakan untuk materi sistem peredaran darah manusia. Dalam e-modul interaktif ini berisi konten materi, latihan soal, dan juga evaluasi dengan berbagai jenis pertanyaan. Hasil akhir e-modul interaktif adalah berformat .apk yang dapat diinstal pada smartphone android.

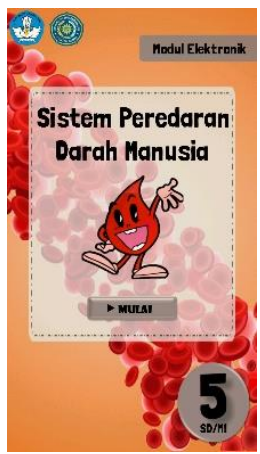

(a) (b)

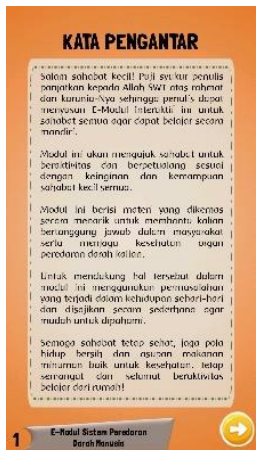

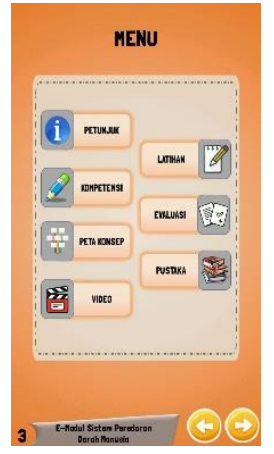

(c)
Gambar 2. Tampilan Pendahuluan: (a) Cover, (b) Kata Pengantar, (c) Menu,
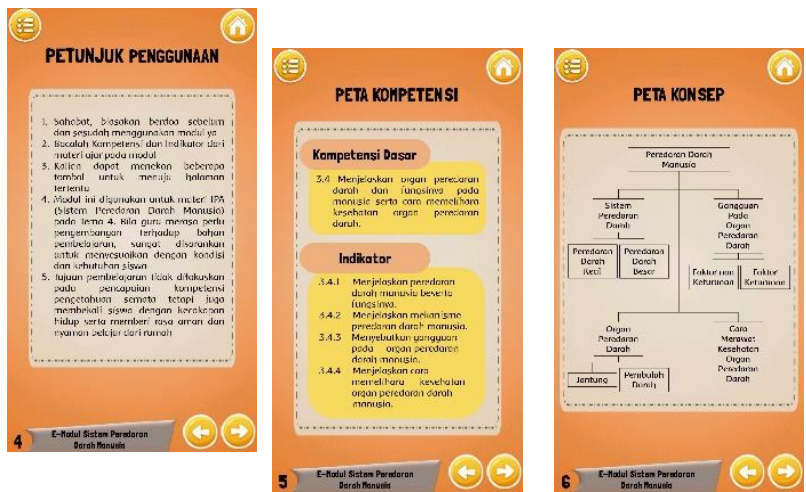

(d) Petunjuk Penggunaan, (e) Peta Kompetensi, (f) Peta Konsep

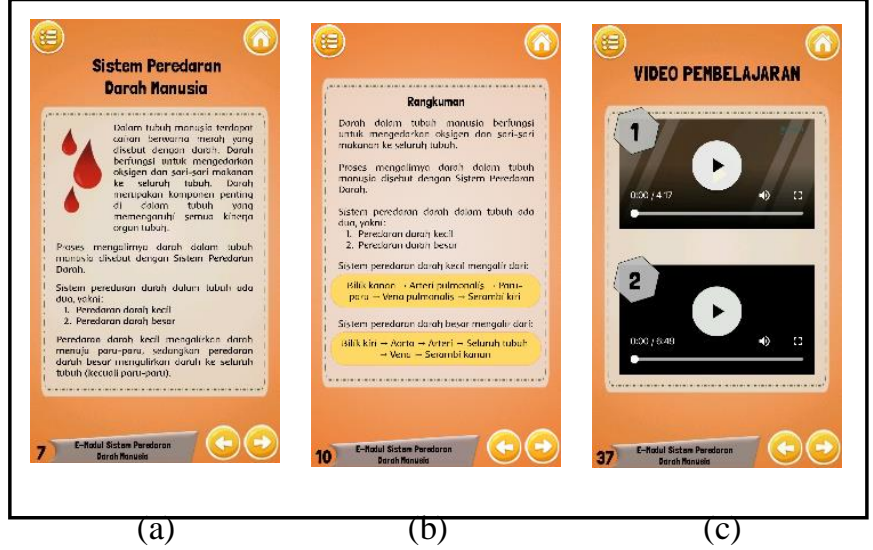

Gambar 3. Tampilan Isi: (a) Uraian Materi, (b) Rangkuman, (c) Video Pembelajaran

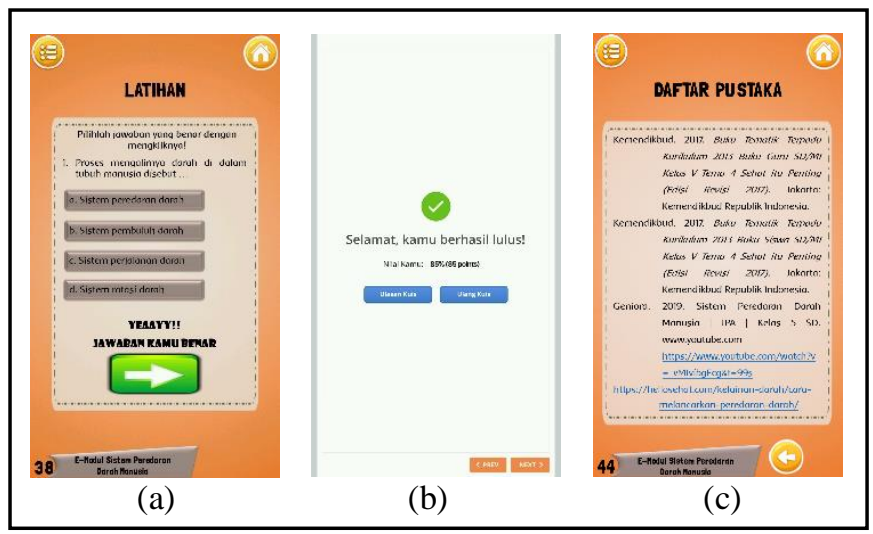

Gambar 4. Tampilan Penutup: (a) Latihan, (b) Hasil Evaluasi, (c) Daftar Pustaka

Tahap define (pendefinisian) dilakukan untuk mencari masalah dan juga kebutuhan dari peserta didik untuk mengembangkan e-modul. Pada tahap ini kegiatan yang dilakukan analisis awal dimana pengumpulan informasi dilakukan melalui observasi. Hasil analisis awal pada pembelajaran jarak jauh (PJJ) guru SDN Kalisari 02 Pagi masih menggunakan media-media yang umum dikenal seperti Whatsapp Grup dan juga video dari YouTube, namun media tersebut kurang mendukung untuk pembelajaran IPA karena cakupannya yang cukup luas dan perlu kegiatan praktik. Siswa pun mengalami kesulitan untuk memahami materi IPA melalui pembelajaran jarak jauh (PJJ). Analisis peserta didik dilakukan untuk mengetahui karakter peserta didik, hasil analisis tersebut peserta didik sulit memahami materi IPA sistem peredaran darah, peserta didik pun sudah terbiasa menggunakan smartphone miliknya dalam proses pembelajaran jarak jauh. Selanjutnya dari hasil analisis tersebut peneliti menentukan isi materi yang akan ditampilkan pada e-modul yang dikembangkan supaya relevan dengan kompetensi dasar dan tujuan pembelajaran yang terdapat pada silabus.

Tahap design (perancangan) penyusunan materi dari berbagai sumber dengan sumber utama dari buku tematik tema 4 kelas $\mathrm{V}$ sekolah dasar. Tampilan pada e-modul 
interaktif dirancang dengan menggunakan media Microsoft PowerPoint yang disesuaikan dengan pengguna aplikasi dan juga bahasan materi. E-modul interaktif ini dibuat dengan bantuan software iSpring Suite dan Website 2 APK Builder sebagai penunjang media pada e-modul ini. Format rancangan e-modul yang dihasilkan sebagai produk awal pengembangan peneliti dapat dilihat pada tabel III.

\section{Tabel III}

Format rancangan produk

\begin{tabular}{|c|c|c|}
\hline $\begin{array}{c}\text { Bagian } \\
\text { Pendahuluan }\end{array}$ & Bagian isi & Bagian Penutup \\
\hline Cover & Kegiatan & Latihan \\
\hline Kata Pengantar & Pembelajaran & Evaluasi \\
\hline Daftar Isi & Uraian Materi & Daftar Pustaka \\
\hline Menu & Rangkuman & \\
\hline Petunjuk Penggunaan & Video Pembelajaran & \\
\hline $\begin{array}{l}\text { KD dan Indikator } \\
\text { Peta Konsep }\end{array}$ & & \\
\hline
\end{tabular}

Tahap development (pengembangan), pada tahap ini setelah produk selesai dikembangkan akan dilakukan pengujian produk oleh tim validasi ahli materi, ahli media, dan ahli modul. Uji coba terbatas pada produk akan dilakukan setelah produk diuji oleh tim validasi ahli. Validasi penelitian dilakukan oleh 6 orang ahli, yakni terdiri dari 2 ahli materi. 2 ahli media, dan 2 ahli modul. Ahli materi adalah dosen yang berkompeten di bidang pendidiskan biologi, ahli media adalah dosen yang berkompeten di bidang media pembelajaran dan rekayasa perangkat lunak, dan ahli modul adalah dosen yang berkompeten di bidang pengembangan bahan ajar dan pembelajaran. Hasil validasi oleh ahli materi dapat dilihat pada tabel IV.

Tabel IV

Hasil Validasi Ahli Materi

\begin{tabular}{cccc}
\hline \multirow{2}{*}{ Aspek } & \multicolumn{2}{c}{ Tim Validator } & \\
\cline { 2 - 3 } & $\begin{array}{c}\text { Ahli Materi } \\
\text { (1) }\end{array}$ & $\begin{array}{c}\text { Ahli Materi } \\
\text { (2) }\end{array}$ & \\
\hline Pembelajaran & $96,43 \%$ & $75 \%$ & Kategori \\
Materi & $83,33 \%$ & $75 \%$ & \\
Evaluasi & $70,83 \%$ & $75 \%$ & \\
\hline \multirow{2}{*}{ Rata-rata } & $83,53 \%$ & $76 \%$ & Baik \\
\cline { 2 - 3 } & \multicolumn{2}{c}{$79,27 \%$} \\
\hline
\end{tabular}

Hasil validasi dari ahli materi rata-rata keseluruhan pada tiap aspek dari 2 validator mendapatkan skor persentase 79,27\% dengan kriteria baik. Perolehan paling kecil pada aspek evaluasi ahli materi 1 dengan skor $70,83 \%$ dan perolehan terbesar pada aspek pembelajaran dari ahli materi 1 dengan skor $96,43 \%$. Untuk hasil validasi ahli media dapat dilihat pada tabel V.

Tabel V

Hasil Validasi Ahli Media

\begin{tabular}{|c|c|c|c|}
\hline \multirow[b]{2}{*}{ Aspek } & \multicolumn{2}{|c|}{ Tim Validator } & \multirow{4}{*}{ Kategori } \\
\hline & $\begin{array}{c}\text { Ahli Media } \\
\text { (1) }\end{array}$ & $\begin{array}{c}\text { Ahli Media } \\
\text { (2) }\end{array}$ & \\
\hline Tampilan & $89,29 \%$ & $75 \%$ & \\
\hline Pemanfaatan & $91,67 \%$ & $70,83 \%$ & \\
\hline
\end{tabular}

\begin{tabular}{|c|c|c|c|}
\hline $\begin{array}{c}\text { Media } \\
\text { Elektronik }\end{array}$ & $100 \%$ & $81,25 \%$ & \\
\hline \multirow{2}{*}{ Rata-rata } & $93,65 \%$ & $75,69 \%$ & \\
\hline & \multicolumn{2}{|c|}{$84,67 \%$} & Baik \\
\hline
\end{tabular}

Hasil validasi dari ahli media rata-rata keseluruhan pada tiap aspek dari 2 validator mendapatkan skor persentase $84,67 \%$ dengan kriteria baik. Perolehan paling kecil pada aspek pemanfaatan ahli media 2 dengan skor $70,83 \%$ dan perolehan terbesar pada aspek media elektronik dari ahli media 1 dengan skor $100 \%$. Selanjutnya hasil validasi ahli modul dapat dilihat pada tabel VI.

\section{Tabel VI}

Hasil Validasi Ahli Modul

\begin{tabular}{cccc}
\hline \multirow{2}{*}{ Aspek } & \multicolumn{2}{c}{ Tim Validator } & \\
\cline { 2 - 3 } & $\begin{array}{c}\text { Ahli Modul } \\
(\mathbf{1})\end{array}$ & $\begin{array}{c}\text { Ahli Modul } \\
\text { (2) }\end{array}$ & \\
\hline Pendahuluan & $100 \%$ & $75 \%$ & Kategori \\
Isi & $88,89 \%$ & $77,78 \%$ & \\
Penutup & $81,25 \%$ & $75 \%$ & \\
\hline \multirow{2}{*}{ Rata-rata } & $90,05 \%$ & $75,93 \%$ & Baik \\
\cline { 2 - 3 } & \multicolumn{3}{c}{$82,99 \%$} \\
\hline
\end{tabular}

Hasil validasi dari ahli modul rata-rata keseluruhan pada tiap aspek dari 2 validator mendapatkan skor persentase 82,99\% dengan kriteria baik. Perolehan paling kecil pada aspek pendahuluan dan penutup ahli modul 2 dengan skor $75 \%$ dan perolehan terbesar pada aspek pendahuluan dari ahli media 1 dengan skor $100 \%$.

Berdasarkan hasil validasi yang diperoleh dari para ahli di tiap aspeknya rata-rata memiliki kategori baik. Hal ini dikarenakan aplikasi yang dibuat telah disesuaikan isi konten dengan silabus dan materi pada kelas 5 yang dimuat dengan tampilan menarik dan memudahkan bagi pengguna. Selain itu, aplikasi sudah dapat berjalan secara normal tanpa gangguan saat digunakan.

Tahap disseminate (penyebaran) produk yang telah dinilai layak oleh tim validasi ahli akan diuji cobakan secara terbata pada SDN Kalisari 02 Pagi saja sebagai tempat penelitian dilakukan. Proses penyebaran produk yang berupa e-modul dalam bentuk aplikasi android (.apk) disebar melalui Whatsapp Grup dengan memberi prosedur pemasangan aplikasi dan juga penggunaannya kepada guru dan peserta didik. Hasil dari uji coba terbatas yang dilakukan untuk melihat respon siswa terhadap produk dapat dilihat pada tabel VII.

Tabel VII

Hasil Uji Coba Terbatas

\begin{tabular}{ccc}
\hline Aspek & $\begin{array}{c}\text { Uji Coba Terbatas } \\
\text { (20 Siswa) }\end{array}$ & \\
\cline { 1 - 2 } Desain & $89 \%$ & Kategori \\
Materi & $86,75 \%$ & \\
Bahasa & $84,25 \%$ & \\
\hline Rata-rata & $86,67 \%$ & Sangat Baik \\
\hline
\end{tabular}


Hasil dari uji coba terbatas menunjukkan hasil rerata sangat baik. Aspek desain mendapatkan perolehan skor persentase paling tinggi yakni dengan skor persentase $89 \%$, dengan mendapatkan perolehan tersebut membuktikan desain tampilan pada aplikasi e-modul interaktif sudah sangat baik dan menarik bagi peserta didik. Hal ini sangat penting untuk memberi kesan awal bagi peserta didik sehingga mereka dapat tertarik untuk belajar menggunakan aplikasi e-modul interaktif tersebut. Hasil uji coba terbatas menunjukkan respon yang sangat baik dari peserta didik di setiap aspeknya.

Berdasarkan penelitian yang dilakukan dan hasil yang didapatkan, aplikasi e-modul interaktif berbasis android layak digunakan sebagai bahan ajar pada materi sistem peredaran darah karena berisikan materi yang cukup lengkap dan mendalam serta memiliki tampilan yang menarik bagi siswa dan penggunaannya yang sangat mudah. Aplikasi e-modul interaktif menjadi aplikasi fleksibel yang dapat digunakan kapan saja, di mana saja, dan memungkinkan siswa untuk digunakan belajar secara mandiri di rumah.

Penggunaan model 4D yang digunakan dalam penelitan pengembangan e-modul interaktif ini atas dasar awal mulanya model tersebut digunakan untuk mengembangkan bahan ajar bagi guru anak-anak berkebutuhan khusus, namun model 4D ini dapat dijadikan ide untuk prosedur pengembangan instruksional (Rochmad, 2012). Selain itu model pengembangan 4D merupakan model yang sistematik, sehingga penggunaannya urut mulai dari pendefinisian sampai penyebaran.

Hasil validasi ahli materi dan ahli modul yang mendapatkan skor rata-rata per aspeknya 79,27\% dengan kategori baik dan $82,99 \%$ dengan kategori baik menunjukkan bahwa isi konten materi dari e-modul interaktif yang dikembangkan sudah baik dan dapat dipelajari oleh siswa secara menyeluruh baik dengan bimbingan guru maupun tidak karena tujuan pembelajaran dalam e-modul sesuai dengan kompetensi yang dicapai. Selain itu pada materi juga disisipkan berbagai gambar pendukung, gambar bergerak (gif), video pembelajaran, dan evaluasi dengan hasil yang dapat diulas kembali secara langsung sehingga siswa dapat mengetahui kesalahannya. Penggunaan e-modul yang berisi soal latihan dengan kunci jawaban yang dapat diulas adalah hal bagus dan mampu meningkatkan kemampuan berpikir kritis (Suarsana, 2013). Dari hal tersebut juga mampu menjadikan pembelajaran lebih bermakna bagi siswa, terlebih dalam pembelajaran IPA tidak hanya berfokus pada pemahaman pengetahuan saja melainkan juga proses yang berpusat pada siswa sehingga mereka dapat menggali potensinya masing-masing (Sintawati, 2021)

Kualitas e-modul yang dikembangkan dari segi media juga dikatakan baik karena berdasarkan hasil validasi ahli media menunjukkan rata-rata skor per aspek $84,67 \%$. E-modul dapat digunakan di mana saja dan kapan saja oleh siswa melalui smartphone miliknya, hasil ini juga menjawab penelitan yang menjelaskan e-modul perlu didukung telepon seluler agar penggunaannya tidak terbatas di kelas saja (Setiyani, 2020)

E-modul interaktif materi sistem peredaran darah yang dikembangkan juga mendapat respon baik dari siswa yang sudah mencoba menggunakannya. Rata-rata keseluruhan aspek mendapat skor 86,67\% dengan kategori baik. Hasil tersebut menunjukkan ketertarikan siswa dalam belajar menggunakan e-modul interaktif. Hal itu dapat mendorong kemampuan literasi siswa sesuai dengan penelitian e-modul interaktif cukup efektif untuk mendorong kemampuan literasi siswa (Raharjo, 2017). Selain itu, e-modul interaktif dapat membantu guru dalam mengajar ketika pembelajaran daring menggunakan tekonlogi agar lebih efisien dan tujuan dapat tercapai secara optimal. Karena teknologi memudahkan guru dan siswa dalam proses pembelajaran baik dalam memperoleh informasi ataupun dalam menyampaikan materi (Latip, 2020).

\section{IV.SIMPULAN}

Penelitian dan pengembangan yang dilakukan menghasilkan produk akhir berupa e-modul interaktif pada materi sistem peredaran darah manusia dalam bentuk aplikasi android (format .apk). Hasil validasi oleh ahli materi mendapat skor persentase sebesar 79,27\% dengan kriteria baik, selanjutnya hasil validasi ahli media mendapat skor persentase $84,67 \%$ dengan kriteria baik, dan hasil validasi ahli modul mendapatkan skor persentase sebesar $82,99 \%$ dengan kriteria baik. Selain itu, hasil uji coba terbatas mendapat skor persentase sebesar $86,67 \%$ dengan kriteria sangat baik. Sehingga hasil ini menunjukkan e-modul interaktif berbasis android layak untuk digunakan sebagai bahan ajar untuk materi sistem peredaran darah manusia kelas V Sekolah Dasar.

Aplikasi e-modul interaktif menjadi inovasi baru yang dalam proses belajar di kelas maupun di rumah. Aplikasi mudah digunakan bagi pengguna dan memiliki cakupan materi yang cukup luas dan dalam, sehingga dengan adanya aplikasi e-modul interaktif ini dapat meningkatkan produktivitas dengan minim tenaga. Ini merupakan sebuah kelebihan dari e-modul yang dibuat dalam bentuk aplikasi android, namun berdasarkan penelitian aplikasi e-modul interaktif yang dikembangkan masih memiliki beberapa kekurangan, yakni hanya dapat diinstal dan digunakan pada smartphone android dan materi dalam e-modul masih terbatas pada sistem peredaran darah manusia.

\section{DAFTAR PUSTAKA}

[1] Lase, (2019) "Pendidikan di Era Revolusi Industri 4.0," SUNDERMANN J. Ilm. Teol. Pendidikan, Sains, Hum. dan Kebud., vol. 1, no. 1, hal. 28-43, doi: https://doi.org/10.36588/sundermann.v1i1.18.

[2] Khairunnisa, G. Amirullah, dan M. Ninawati, (2019) "Development of Learning Android Media-Based Mobile Learning Applications in Courses Basic Concepts of Natural Sciences," J. Inov. Pendidik. Dasar, vol. 4, no. 2, hal. 49-56, doi: 10.22236/jipd.v4i2.80.

[3] Sidiq dan Najuah (2020)"Pengembangan E-Modul Interaktif Berbasis Android pada Mata Kuliah Strategi Belajar Mengajar," J. Pendidik. Sej., vol. 9, no. 1, hal. 14, doi: Doi.org/10.21009/jps.091.01.

[4] Purwanto, R. Aristo, dan L. Suharto (2007) Pengembangan Modul Seri Teknologi Pembelajaran. Jakarta: PUSTEKKOM Depdiknas.

[5] Herawati dan A. Muhtadi, (2018)"Pengembangan modul elektronik (e-modul) interaktif pada mata pelajaran Kimia 
kelas XI SMA,” J. Inov. Teknol. Pendidik., vol. 5, no. 2, hal. 180-191, Okt doi: http://dx.doi.org/10.21831/jitp.v5i2.15424.

[6] Kusuma dan Hamidah (2020) "Perbandingan Hasil Belajar Matematika Dengan Penggunaan Platform Whatsapp Group Dan Webinar Zoom Dalam Pembelajaran Jarak Jauh Pada Masa Pandemik Covid 19," JIPMat, vol. 5, no. 1, doi: 10.26877/jipmat.v5i1.5942.

[7] L. D. Herliandry, Nurhasanah, M. E. Suban, dan H. Kuswanto, "Pembelajaran Pada Masa Pandemi Covid-19," JTP - J. Teknol. Pendidik., vol. 22, no. 1, hal. 65-70, 2020, doi: https://doi.org/10.21009/jtp.v22i1.15286.

[8] Rasyidiana, (2021) "Problematika Pembelajaran Daring Pada Mata Pelajaran Sains (IPA) Tingkat Dasar Di Masa Pandemi Covid-19," J. basicedu, vol. 5, no. 4, hal. 1709-1716, doi: https://doi.org/10.31004/basicedu.v5i4.948.

[9] Istiyanto, (2013). Pemrograman Smart Phone Menggunakan SDK Android dan Hacking Android, 1 ed. Yogyakarta: Graha Ilmu,

[10] Liana, Y. R. \& Ellianawati, W. Hardyanto, (2019, "Pengembangan E-Modul Interaktif Berbasis Android Menggunakan Sigil Software pada Materi Listrik Dinamis," Semin. Nas. Pascasarj. Univ. Negeri Semarang, vol. 2, no. 1, hal. 926-932, Diakses: Jan 30, [Daring]. Tersedia pada: https://proceeding.unnes.ac.id/index.php/snpasca/article/view/3 94.

[11] Setiyani, Dkk (2020) "Designing a Digital Teaching Module Based on Mathematical Communication in Relation and Function," J. Math. Educ., vol. 11, no. 2, hal. 223-236, doi: http://doi.org/10.22342/jme.11.2.7320.223-236.

[12] Accraf, Suryati \& Khery, (2018) "Pengembangan E-modul Interaktif Berbasis Android dan Nature of Science Pada Materi Ikatan Kimia dan Gaya Antar Molekul Untuk Menumbuhkan Literasi Sains Siswa," Hydrog. J. Kependidikan Kim., vol. 6, no. 2, hal. 133-141, doi: 10.33394/hjkk.v6i2.1607.

[13] Raharjo, Suryati, \& Khery (2017) "Pengembangan E-Modul Interaktif Menggunakan Adobe Flash Pada Materi Ikatan Kimia Untuk Mendorong Literasi Siswa," Hydrog. J. Kependidikan Kim., vol. 5, no. 1, hal. 8-13, doi: 10.33394/hjkk.v5i1.102.

[14] Wulandari (2020) "Pengembangan Modul Berbasis Software iSpring Suite 9 Pada Mata Kuliah Konsep Dasar IPA 1 Materi Ekosistem Bagi Mahasiswa Program Studi PGSD FKIP UHAMKA," Universitas Muhammadiyah Prof. Dr. Hamka.

[15] Sugiyono (2016) Metode Penelitian Pendidikan Kuantitatif, Kualitatif dan $R \& D$. Bandung

[16] Wahyudi, (2019)"Pengembangan E-Modul dalam Pembelajaran Matematika SMA Berbasis Android," GAUSS J. Pendidik. Mat., vol. 2, no. 2, hal. 10, doi: 10.30656/gauss.v2i2.1739.

[17] Hasanah, H (2016) "Tekni-teknik Observasi (Sebuah Alternatif Metode Pengumpulan Data Kualitatif Ilmu-ilmu Sosial)," AtTaqaddum, vol. 8, no. 1, hal. 25, doi: 10.21580/at.v8i1.1163.

[18] Rochmad, (2012) "Desain Model Pengembangan Perangkat Pembelajaran Matematika," Kreano J. Mat. Kreat., vol. 3, no 1, hal. 59-72, doi: https://doi.org/10.15294/kreano.v3i1.2613.

[19] Suarsana dan G. A. Mahayukti (2013) "Pengembangan EModul Berorientasi Pemecahan Masalah Untuk Meningkatkan Keterampilan Beripikir Kritis Mahasiswa," J. Pendidik. Indones., vol. 2, no. 2, hal. 264-275, doi: http://dx.doi.org/10.23887/jpi-undiksha.v2i2.2171.

[20] Sintawati dan I. G. Margunayasa (2021) "Interactive E-Module for Science Learning Content: Validity and Feasibility," vol. 5, no. $1, \quad$ hal. 19-29, doi: http://dx.doi.org/10.23887/ijee.v5i1.34281.

[21] A. Latip, (2020) "Peran Literasi Teknologi Informasi dan
Komunikasi Pada Pembelajaran Jarak Jauh di Masa Pandemi Covid-19," EduTeach J. Edukasi Dan Teknol. Pembelajaran, vol. 1, no. 2, hal. 107-115, doi: https://doi.org/https://doi.org/10.37859/eduteach.v1i2.1956. 